ZOOLOGIA 28 (5): 603-609, October, 2011

doi: $10.1590 /$ S1984-46702011000500008

\title{
The reproductive biology of the plata pompano, Trachinotus marginatus (Teleostei: Carangidae), in southern Brazil
}

\author{
Valéria M. Lemos¹,3; Antônio S. Varela Junior²; Gonzalo Velascoํ \& João P. Vieira1 \\ ${ }^{1}$ Instituto de Oceanografia, Universidade Federal do Rio Grande. Avenida Itália km 8, Carreiros, 96201-900 Rio Grande, RS, \\ Brazil. \\ ${ }^{2}$ Laboratório de Histologia, Instituto Ciências Biológicas, Universidade Federal do Rio Grande. Avenida Itália, km 8, Campus \\ Carreiro, 96203-000 Rio Grande, RS, Brazil. \\ ${ }^{3}$ Corresponding author. E-mail: vavadeleom@yahoo.com.br
}

\begin{abstract}
The Plata pompano, Trachinotus marginatus (Cuvier, 1832), is an endemic carangid of the Southwestern Atlantic Ocean, occurring from Rio de Janeiro to Uruguay. This study describes the reproductive period, spawning type, the size at first gonadal maturation and the length-weight relationship of individuals sampled from landings of the artisanal and commercial fishing fleets in Rio Grande that operate along the coast of Rio Grande do Sul state, southern Brazil $\left(\sim 32^{\circ} \mathrm{S}\right)$ to the Uruguayan border $\left(\sim 34^{\circ} \mathrm{S}\right)$. Monthly collections from September 2008 through January 2010 yielded 274 individuals ranging from 142 to $444 \mathrm{~mm}$ in total length (TL). The gonadal development stages were defined according to the histological examination of the ovaries and the testes. The relationship between TL $(\mathrm{mm})$ and total weight TW $(\mathrm{g})$ was statistically different between males $\left(\mathrm{TW}=0.000463^{*} \mathrm{TL}^{2.7655}\right)$ and females $(\mathrm{TW}=$ $\left.0.000361^{*} \mathrm{TL}^{2.8131}\right)$, showing negative allometric growth for both sexes. The sizes at first maturity were $187.2 \mathrm{~mm}$ and $254.9 \mathrm{~mm}$ for females and males, respectively. The presence of two modal groups of oocyte diameters suggested that total spawning occurred. The interpretation of the monthly variations of the condition factor and gonadosomatic index, which are associated with higher frequencies of the more advanced stages of gonadal development, identified the spring and summer months as the reproductive period, with a peak in the reproductive activity during November and January. These results suggested that the species has an opportunistic reproductive strategy.
\end{abstract}

KEY WORDS. Reproductive period; sexual maturation; spawning; weight-length relationship.

Trachinotus marginatus (Cuvier, 1832) is an endemic carangid of the Southwestern Atlantic Ocean, occurring from Rio de Janeiro to the coast of Uruguay (Menezes \& Figueiredo 1980, RetTA et al. 2006). The juveniles of this species are widely distributed in the surf zone of sandy beaches whereas the adults are found in deeper waters (RAmos \& Vieira 2001, Godefroid et al. 2003, Monteiro-Neto et al. 2003, Vasconcellos et al. 2007, Lima \& VieIRA 2009).

Previous studies of T. marginatus in Rio Grande do Sul described its natural feeding habits (MonTeIro-Neto \& CunHA 1990), behavioral responses in captivity and survival rates in relation to salinity and oxygen consumption (TESSER et al. 1998, SAMPAIO et al. 2003). Moreover, Martins \& Bianchini (2008) used the species as a model in toxicity tests. Although the above-mentioned works furnish important information about the biology of $T$. marginatus, no published studies address its reproduction.

The knowledge of the reproductive biology of fishes is essential for the effective management of fish populations as fishery resources. Biological parameters, such as the size at first maturity, oocyte diameter and gonadosomatic index variation, may indicate the breeding season, sexual maturation and spawn- ing (HeIns et al. 2004). In addition, length-weight relationships may be used to estimate biomass from length-frequency data and may serve as a measure of the expected weight variation at a given length, thus, indicating the individual's condition, fat accumulation and gonadal development (Rossi-WoNGTSCHOWSKI 1977).

This report provides new information on the mean size at first maturity $\left(\mathrm{L}_{50}\right)$, reproductive period, spawning type, and weight-length relationship for T. marginatus to address the lack of knowledge of its reproductive biology and to impart essential information to guide management actions and conservation for the species.

\section{MATERIAL AND METHODS}

The specimens were collected monthly from November 2008 through January 2010 from landings of the artisanal and commercial fishing fleets in Rio Grande that operate along the coast of Rio Grande do Sul state, southern Brazil, from Rio Grande city $\left(\sim 32^{\circ} \mathrm{S}\right)$ to the Uruguayan border $\left(\sim 34^{\circ} \mathrm{S}\right)$. We examined a total of 274 individuals of T. marginatus. The speci- 
mens were kept on ice prior to the same-day data collection in the laboratory. The total length (TL - from the tip of the snout to the end of the caudal fin in the normal position) in mm was measured with an ichthyometer, and the total weight (TW), gonad weight $(\mathrm{GW})$, and body weight $(\mathrm{BW}=\mathrm{TW}-\mathrm{GW})$ in grams $(\mathrm{g})$ were measured using an electronic scale $(0.01$-g precision). The gonads were extracted and fixed in a $10 \%$ buffered formalin solution (for approximately seven days) and then kept in $70 \%$ ethanol. Gonad fragments from all of the specimens collected were analyzed using a routine histological procedure that consisted of dehydration through an ascending ethanol series, diaphanization with xylol, inclusion in Paraplast Xtra at $58^{\circ} \mathrm{C}$, microtomy to produce 5 - to $7-\mu \mathrm{m}$ sections, and staining with hematoxylin-eosin (HE) (BeÇAK \& Paulete 1976).

All of the histological sections were photographed on a microscope (BX-51) with a coupled digital camera (DP-72 Olympus). For each ovary, approximately 20 randomly selected oocytes were measured using ImageJ software (BURGER \& BURGE 2007) to determine the oocyte diameters at different developmental stages. The oocyte developmental pattern was determined in terms of the distribution of the different stages of the germ cells.

The Gonadosomatic Index (GSI $\left.=\mathrm{GW} / \mathrm{BW}^{*} 100\right)$ and the Somatic $\left(\mathrm{K}^{\prime}=\mathrm{BW} / \mathrm{TL}^{\mathrm{b}}\right)$ and Allometric $\left(\mathrm{K}^{\prime \prime}=\mathrm{TW} / \mathrm{TL}^{\mathrm{b}}\right)$ Condition Factors were calculated from the angular coefficient $(b)$ of the linear regression of the logarithm of weight on the logarithm of length. The gonad Condition Factor $(\Delta \mathrm{K})$ was obtained as $\mathrm{K}^{\prime \prime}-\mathrm{K}^{\prime}$, on the basis of the assumption that the period with the highest mean for the slope corresponds to the reproductive period because much of the energy accumulated by the individual has been allocated to the gonads (VAzzoler 1996). The reproductive period was established for both sexes using the monthly variation in the GSI and $\Delta \mathrm{K}$ scores and the frequencies of the gonadal maturation stages for the specimens collected from September 2008 through August 2009.

The degree of gonadal maturation was based on the variation in the histological characteristics of the gonads and the frequency distribution of the gonadal development stages using the following five-stage scale adapted from VAzzOLER (1996): immature or virgin, in maturation, mature, hyalinized/females, and reabsorption/females.
The mean length at first maturity $\left(\mathrm{L}_{50}\right)$ was determined from the relative frequency distribution of mature individuals according to the total-length class, and the calculation was based on both sexes because of the small number of individuals examined. A sigmoid curve was obtained by fitting the following logistic equation: $P M=1 / 1+e^{\left(-a+b^{*} L T\right)}$, where PM is the relative proportion of mature individuals, TL is the total length $(\mathrm{mm})$, and $a$ and $b$ are constants to be iteratively estimated with a nonlinear least-squares procedure. The mean size at first maturity corresponds to the inflection point of the sigmoid curve; at this size, $50 \%$ of the individuals are mature (BEVERTON 1992).

The relationship between weight and length was calculated for both sexes through the following model: TW $=\mathrm{a}^{\star} \mathrm{TL}^{\mathrm{b}}$ (LE CREN 1951), where $a$ is the coefficient related to the increase in weight and $b$ represents the allometric coefficient describing the individuals' growth type (KING 1995). The model was fitted with nonlinear regression by least squares (ZAR 1999). The GaussNewton algorithm was used to perform the iterations (MYers 1990). Student's t-test (ZAR 1999) was used to determine whether $b$ differed significantly from three, thus, defining allometric growth (if $b=3$, the growth is isometric) and to test differences in the coefficients between the males and females.

\section{RESULTS}

Of the 274 specimens examined, $102(37.2 \%)$ were males $(142 \mathrm{~mm} \leqslant \mathrm{TL} \leqslant 416 \mathrm{~mm})$ and $134(48.9 \%)$ were females (144 $\mathrm{mm} \leqslant \mathrm{TL} \leqslant 444 \mathrm{~mm}$ ). The sex of 38 additional specimens could not be determined.

The range of maturity for the females was based on the presence and frequency of the developmental stages of the ovarian follicle and included five stages of development with different characteristics (Tab. I). Testicular development in the males was classified into three stages (Tab. II).

The weight-length relationship for T. marginatus was TW $=0.000463^{*} \mathrm{TL}^{2.7655}$ for females and TW $=0.000361^{*} \mathrm{TL}^{2.8131}$ for males (Fig. 1), and the $b$ coefficients were significantly different for males and females $(\mathrm{p}<0.05)$. Both sexes showed negative allometric growth, with values for the $b$ coefficient that were lower than the isometric value $(3.0)(\mathrm{p}<0.05)$.

Table I. Characteristics of the ovarian stages of female Trachinotus marginatus.

\begin{tabular}{lccccc}
\hline \multirow{2}{*}{ Characteristics } & \multicolumn{5}{c}{ Ovarian stage } \\
\cline { 2 - 6 } & Immature & Maturation & Mature & Hyalinized & Ovary in reabsorption \\
\hline Mean IGS & 0.29 & 1.82 & 2.12 & 195.85 & 0.38 \\
Size in relation to abdominal cavity & $<1 / 3$ & $<1 / 3$ & $<2 / 3$ & $2 / 3$ & $1 / 3$ \\
Perception of oocytes & No & No & Yes & High & Few \\
Vascularization & No & Little & High & High & Hemorrhagic \\
Coloration of the ovaries & Translucent & Clear pink & Yellow & Yellow red & Yellow \\
Weight (g) & $0.11 \pm 0.07$ & $0.57 \pm 0.42$ & $2.12 \pm 1.65$ & $40.0 \pm 18.56$ & $0.48 \pm 0.38$ \\
\hline
\end{tabular}

ZOOLOGIA 28 (5): 603-609, October, 2011 

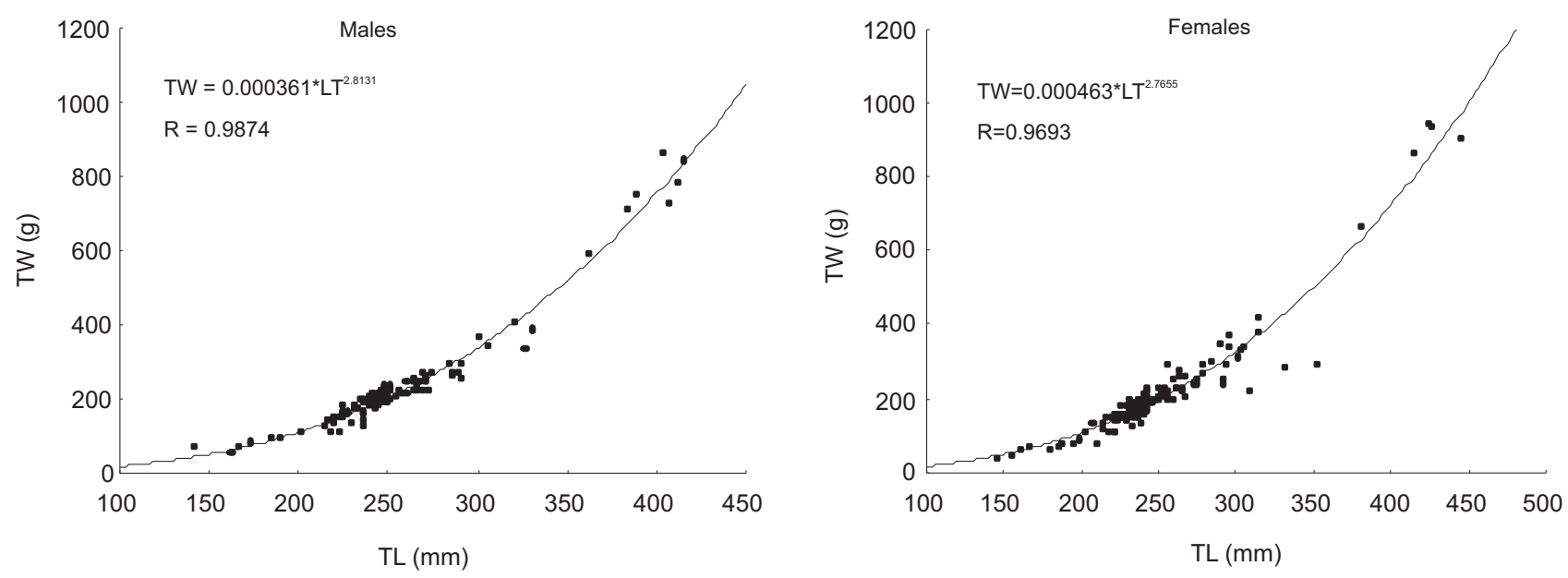

Figure 1. The length-weight relationship for the males and females of Trachinotus marginatus.

Table II. Characteristics of the testicular stages of male Trachinotus marginatus.

\begin{tabular}{lccc}
\hline \multirow{2}{*}{ Characteristics } & \multicolumn{3}{c}{ Testicular stages } \\
\cline { 2 - 4 } & Immature & Maturation & Mature \\
\hline Mean IGS & 0.13 & 1.31 & 2.26 \\
$\begin{array}{l}\text { Size in relation to } \\
\text { abdominal cavity }\end{array}$ & $<1 / 3$ & $<1 / 3$ & $1 / 3$ \\
$\begin{array}{l}\text { Coloration of the testis } \\
\text { Weight (g) }\end{array}$ & Translucent & White & Yellow \\
\hline
\end{tabular}

The highest incidence of mature individuals was observed from November through February (Figs 2 and 3). Females with hyalinized ovaries, representing the last stage of maturity and indicating imminent spawning, were found only during those months. During December, January and February, 100\% of the males collected were mature.

The monthly variation in the Gonadosomatic Index (GSI) and the gonad Condition Factor $(\Delta K)$ showed peaks in November for the females and January for the males (Figs 4 and 5). In general, the values for the female gonad Condition Factor were much higher than for the males, but similar monthly fluctuation patterns occurred for both sexes.

The presence of two modal groups in the frequency-distribution analysis of the oocyte diameters in the immature stage (Figs 6-10) revealed that the species shows synchronous oocyte development. This finding suggests total spawning. The first group (on the left-hand side of the graph) represents reserve-stock oocytes, present in all stages, and the second group (on the right-hand side) shows a modal displacement in size during development, that is, a maturation process. These maturing oocytes are ultimately released during the reproductive period.

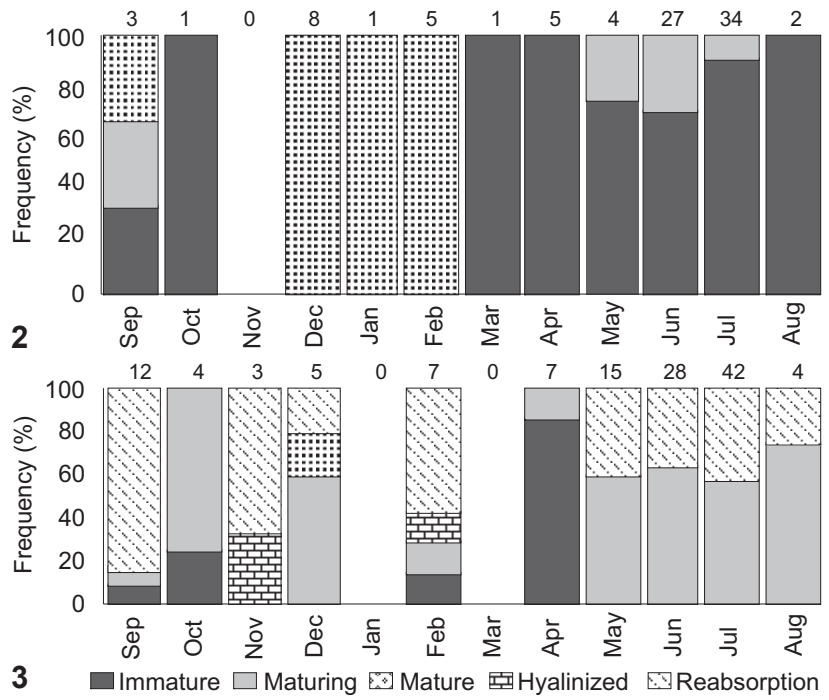

Figures 2-3. Monthly variation in the frequencies of the gonadal maturity stages determined from microscopic observation of the gonads for males (2) and females (3) of T. marginatus collected in southern Brazil from September 2008 through August 2009.

The males of T. marginatus attain sexual maturity at 254.9 $\mathrm{mm}$ TL whereas the females reach sexual maturity at smaller sizes $(187.2 \mathrm{~mm} \mathrm{TL})$. The mean size at first maturity $\left(\mathrm{L}_{50}\right)$ for both sexes was $211.48 \mathrm{~mm} \mathrm{TL}$, and the equation for the $\mathrm{L}_{50}$ adjustment was $\mathrm{PM}=1 / 1+\mathrm{e}^{\left(7.6749-0.03629^{\star L T}\right)}$ (Figs 11-13).

\section{DISCUSSION}

The length-weight relationship is a very useful tool in fisheries assessment and the study of fish populations and is 

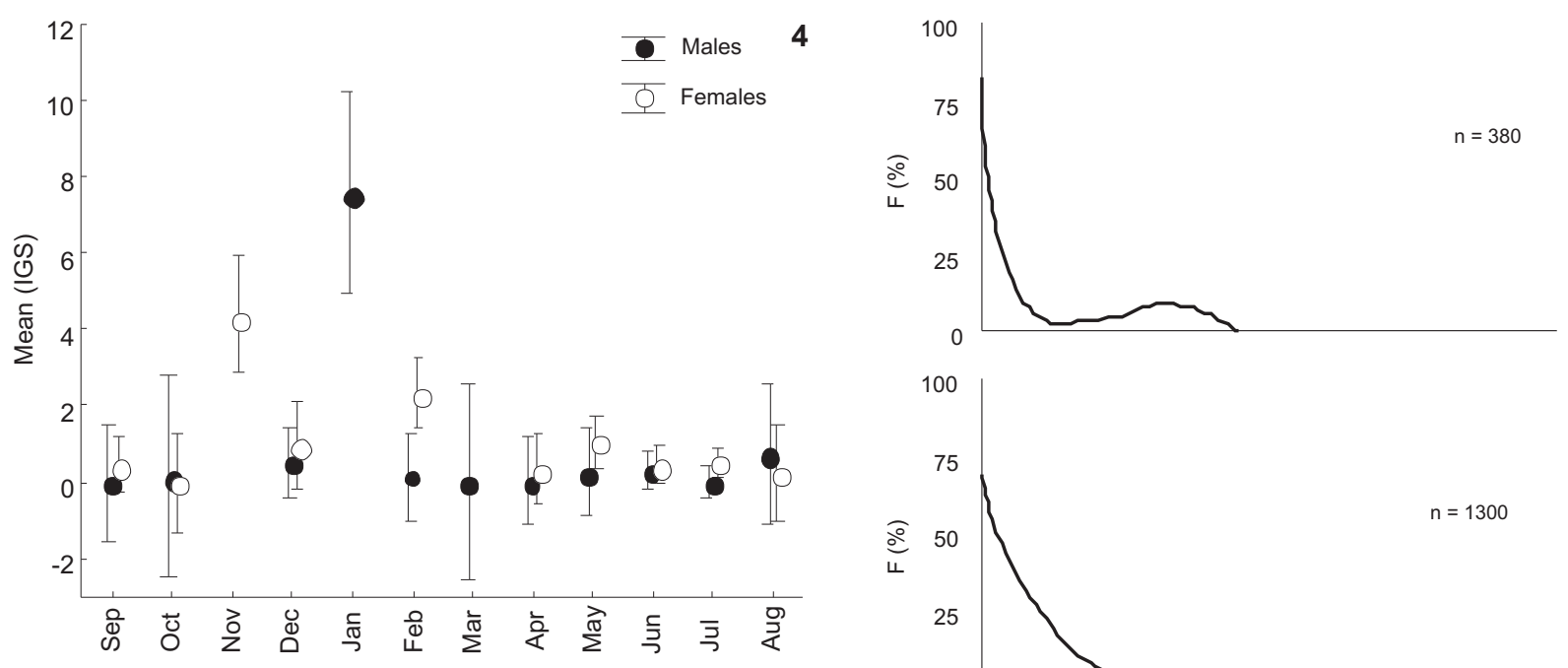

6

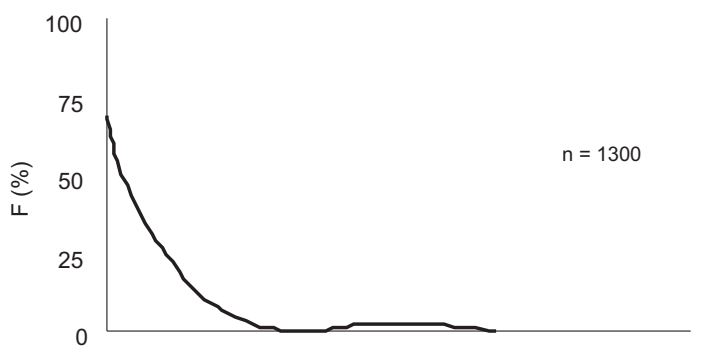

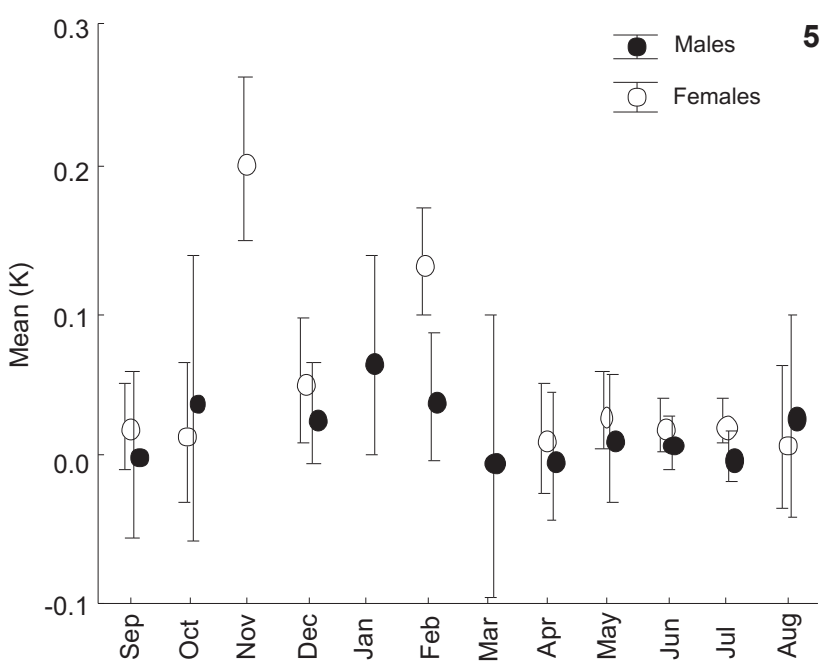

Figures 4-5. Mean values of GSI (4) and $\Delta K$ (5) for females and males of Trachinotus marginatus in southern Brazil from September 2008 through August 2009. Intervals represent the standard deviations of the monthly averages.

used primarily to understand the life cycle of a given species population (Le Cren 1951, OniYe et al. 2006, Haimovici \& Velasco 2000) and to provide information on the ecology of the species (King 1995, Morato et al. 2001). As it is generally easier to measure length than weight, the weight may later be predicted by using this relationship (BRAGA 1993).

The exact relationship between length and weight differs among fish species. BAgENAL \& TESCH (1978) suggested that the $b$ coefficient may vary among congeneric species and stocks of the same species. In the present study, the $b$ values for the females and males of T. marginatus were 2.78 and 2.81, respectively. These values characterize negative allometric growth for
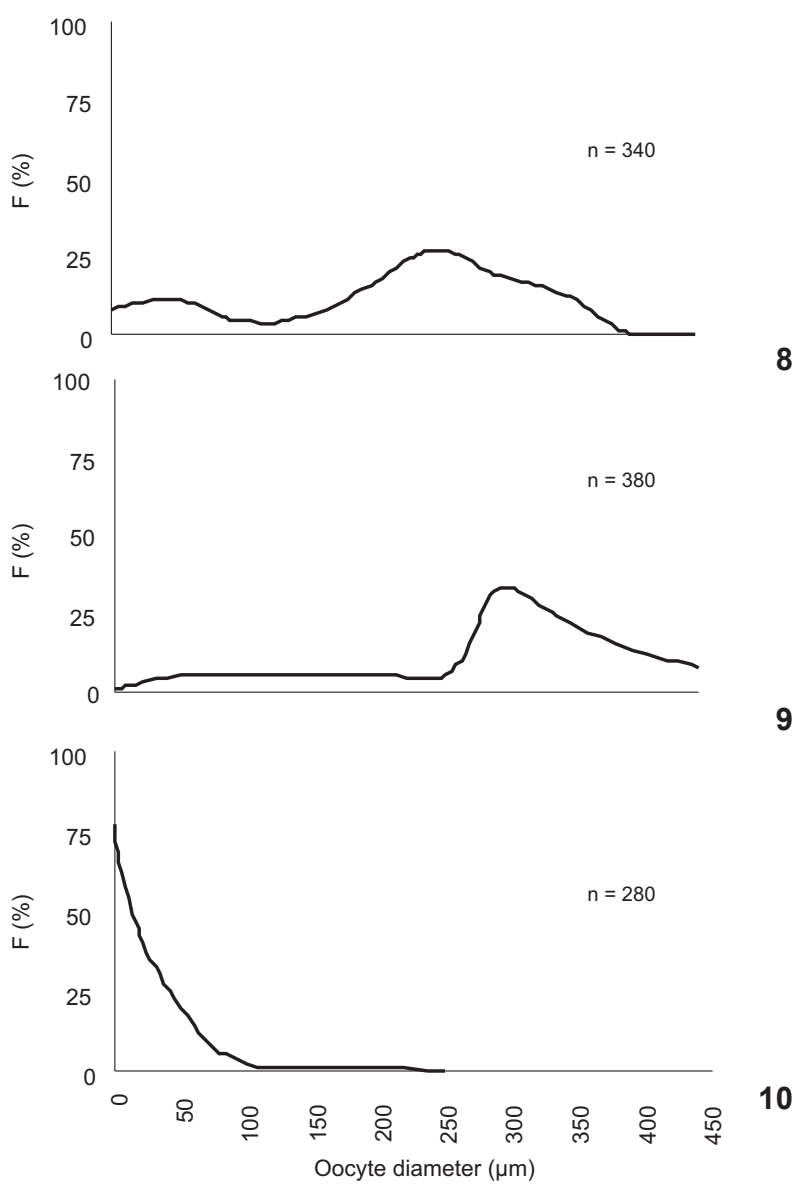

Figures 6-10. Frequency distribution of the percentages of oocyte diameters in Trachinotus marginatus corresponding to each gonadal maturity stage: (6) immature; (7) maturation; (8) mature; (9) hyalinized; (10) ovary in reabsorption. 

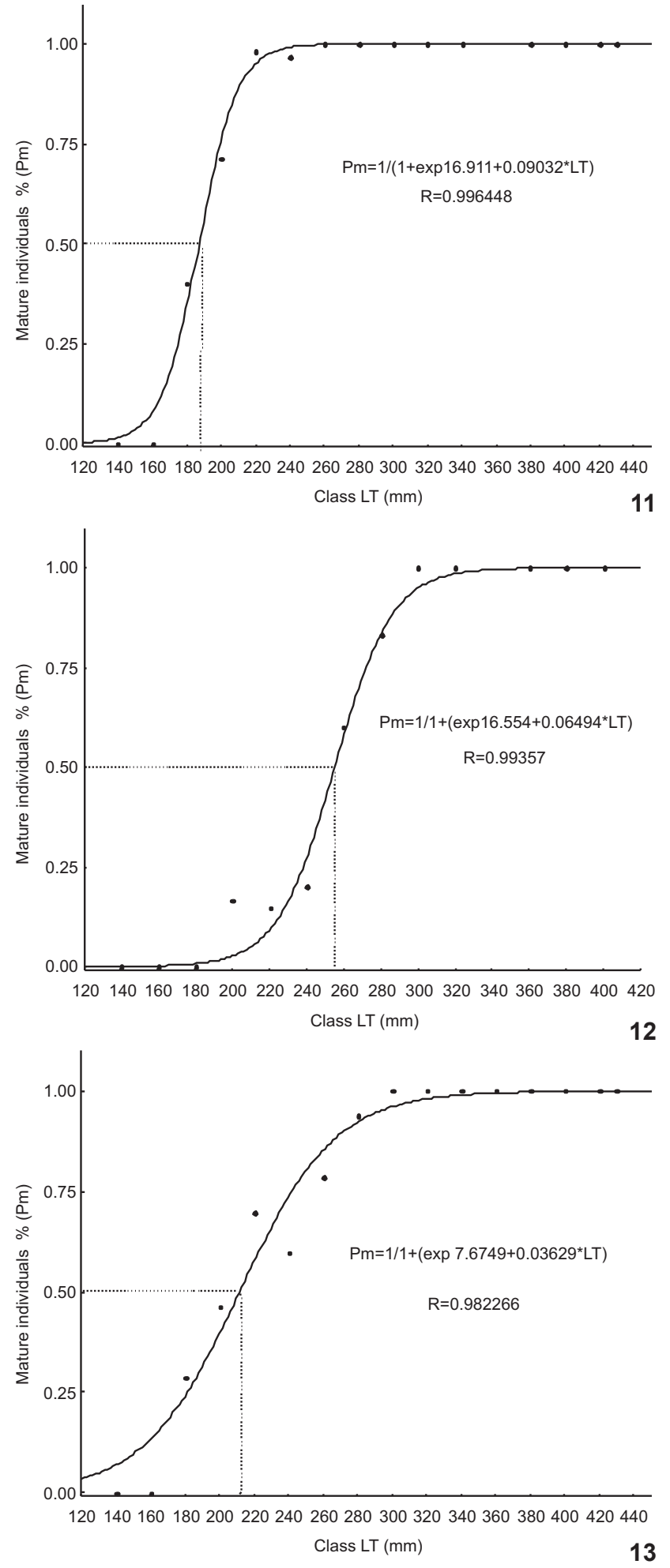

Figure 11-13. Size at first maturity $\left(L_{50}\right)$ of Trachinotus marginatus for females (11), males (12) and grouped sexes (13) in southern Brazil. both genders (Le Cren 1951), and, as indicated by KumoluJoHnson \& NDimele (2010), most fish species have negative allometric growth. Such a growth pattern was also found for other species, such as Trachinotus ovatus (Linnaeus, 1758) in the North Atlantic (Morato et al. 2001), Trachinotus carolinus (Linnaeus, 1766) in Colombia (DuARTe et al. 1999), and Trachinotus falcatus (Linnaeus, 1758) and Trachinotus goodei Jordan \& Evermann, 1896 in the Gulf of Mexico (GonZÁLes-Gándara et al. 2003).

Although both sexes showed negative allometry, the females of T. marginatus had a lower allometry coefficient. This difference may be explained by the more rapid development of the female gonads relative to the increase in the length or weight of the fish, with marked changes in the body shape of the females occurring throughout the sexual cycle (ANGELEscu et al. 1958). Nikolsky (1963) referred to sexual differences in the body size and length-weight relationship as the most frequent form of sexual dimorphism among fish. The size of males is affected by sexual selection, with larger males enjoying a reproductive advantage (SHINE 1990). Moreover, the growth differential between the sexes may represent endogenous influences, such as genetics and hormonal action (Royce 1972).

Growth plays an important role in population dynamics and fisheries ecology (BEvERTON 1992) and is directly affected by temperature, feeding, spawning, and age (RICKER 1973), with a close association with the size or age of the species at first maturity (BARBIERI et al. 2004). The onset of sexual maturity plays an important role and sheds light on the life history of a given species during its evolution (Lessels 1991). The females of $T$. marginatus reached first maturity at smaller sizes than the males. It is generally accepted that the optimal size at first reproduction depends upon many factors, including the relative allocation of energy between somatic and gonadal growth (Роттs \& WootTon 1984).

With the exception of $T$. falcatus, which matures at approximately $500 \mathrm{~mm}$ TL and grows to more than one meter (Crabtree et al. 2002), the vast majority of Trachinotus species, including T. marginatus $\left(\mathrm{L}_{50}=211.5 \mathrm{~mm} \mathrm{TL}\right)$, mature at approximately 200 mm TL (Gómez 2002, Sylla et al. 2009). This relatively small size at maturity indicates the occurrence of precocious sexual maturation for species, such as Trachinotus teraia Cuvier in Cuvier and Valenciennes, 1832 (SMith-Vaniz et al. 1990) and T. goodei (Gómez 2002), which may reach $\mathrm{L}_{\max }$ values of $700 \mathrm{~mm}$. This strategy may be considered a positive tactic for obtaining reproductive success. Indeed, most Trachinotus species occupy highly variable environments (BARBIERI et al. 2004), and it has been suggested that early maturity can be related to an adaptive behavior that compensates for high juvenile losses as a consequence of the environmental stress that influences local recruitment.

Trachinotus marginatus showed a spawning period lasting from late spring through the end of summer (November through February). The highest GSI scores and the higher frequencies of the most-advanced gonadal stages in these warmer months sup- 
ported this finding. Nevertheless, the GSI and $\Delta \mathrm{K}$ did not present values as high as expected for December. This inconsistency may be explained by the relatively few specimens that were obtained for analysis in that month. The Condition Factor is an index related to the gonadal cycle (Lima-Junior et al. 2002) and is frequently used to show seasonal variations in biological parameters. An increase in the Condition Factor from the end of spring towards the summer was also an indication that the species was physiologically prepared for reproduction during that period.

The females showed higher mean GSI values than the males, as is also the case for T. teraia on the African coast (Sylla et al. 2009). Such a pattern is due primarily to the females' higher gonadal development relative to the males, a common occurrence among teleost fish.

According to the pattern of female germ cell developmental dynamics, T. marginatus is an iteroparous species with synchronous oocyte development in two groups and with total spawning. Thus, it is concluded that $T$. marginatus presents a short, well-defined spawning period that is associated with total spawning and is restricted to the warmest period of the year in the southern hemisphere (i.e., November-February).

The occurrence of total spawning, the brief reproductive period and the early sexual maturity of T. marginatus show that the species has an opportunistic reproductive strategy. However, this study is the first work to address a number of aspects of reproduction in this species. Therefore, further studies are needed to test this hypothesis.

\section{ACKNOWLEDGEMENTS}

Conselho Nacional de Desenvolvimento Científico e Tecnológico (CNPq) provided a master's fellowship to Valéria M. Lemos.

\section{LITERATURE CITED}

Angelescu, V.; F.S. Gneri \& A. NAni. 1958. La merluza del mar argentino (biologia y taxonomia). Buenos Aires, Servicio de Hidrografia Naval (H 1004): 1-224.

Bagenal, T.B. \& F.W. Tesch. 1978. Age and growth, p. 101-136. In: T. Bagenal (Ed.). Methods for Assessment of Fish in Freshwaters. Oxford, IBP Handbook Blackwell Scientific Publications, 365p.

Barbieri, G.; F.A. Salles; M.A. Cestarolli \& A.R. Teixeira Filho. 2004. Estratégias reprodutivas do dourado Salminus maxillosus e do curimbatá, Prochilodus lineatus, no Rio Mogi Guaçu, São Paulo, com ênfase nos parâmetros matemáticos da dinâmica populacional. Acta Scientiarium 26 (2): 169-174.

BeçaK, W. \& J. Paulete. 1976. Técnicas de Citologia e Histologia. Rio de Janeiro, Livros Técnicos e Científicos. Editora, 574p.

Beverton, R.J.H. 1992. Patterns of reproduction strategy parameters in some teleosts fishes. Journal of Fish Biology (41): 137-160.
BragA, F.M.S. 1993. Análise do fator de condição de Paralonchurus brasiliensis (Perciformes, Sciaenidae). Maringá, Revista Unimar 15 (2): 99-115.

Burger, W. \& M.J. Burge. 2007. Digital Image Processing: An Algorithmic Approach Using Java. Springer, ISBN 184628 3795. Available online at: http://www.imagingbook.com [Accessed: 06/VII/2010]

Crabtree, R.E.; P.B. Hood \& D. Snodgrass. 2002. Age, growth, and reproduction of permit (Trachinotus falcatus) in Florida waters. Fish Bulletin 100: 26-34.

Duarte, L.O.; C.B. García; N. Sandoval; D. Von Schiller; G. Melo \& P. NAVAJAS. 1999. Length weight relationships of demersal fishes from the Gulf of Salamanca, Colombia. NAGA, World Fish Center Quarterly 22 (1): 34-36.

Godefroid, R.S.; H.L. Spach; R.J. Schwarz \& M.G. Queiroz. 2003. A fauna de peixes da praia do Balneário Atami, Paraná, Brasil. Revista Atlântica 25 (2): 147-161.

Gómez, A. 2002. Selección de peces marinos para cultivos intensivos em el nororiente de Venezuela. Boletín de Investigaciones Marinas y Costeras Santa Marta (31): 53-63.

González-Gándara, C.; E. Pérez-Díaz; L. Santos-Rodríguez \& J.E. Arias-GonZÁlez. 2003. Length-weight relationships of coral reef fishes from the Alacran Reef, Yucatan, Mexico. World fish Center Quart 26 (1): 14-16.

Haimovici M. \& G. Velasco. 2000. Relações comprimento peso de peixes teleósteos marinhos do sul do Brasil com uma avaliação de diferentes métodos de ajuste. Rio Grande, Atlântica 22: 131-140.

HeINS, D.C.; J.A. BAKER \& J.M. GUILL. 2004. Seasonal and inter annual components of intra population variation in clutch size and egg size of a darter. Ecology of Freshwater Fish 13: 258-265.

Kumolu-Johnson, C.A. \& P.E. Ndimele. 2010. Length-weight relationships and condition factors of twenty-one fish species in Ologe Lagoon, Nigeria. Asian Journal of Agricultural Sciences 2: 174-179.

KING, M. 1995. Fisheries biology, assessment and management. Oxford, Fishing News Books, Blackwell Science, 341p.

Le Cren, E.D. 1951. The length-weight relationship and seasonal cycle in gonadal weight and condition in the perch (Perca fluviatilis). Journal of Animal Ecology 20 (20): 1-19.

Lessels, C.M. 1991. The evolution of life histories, p. 32-68. In: J.R. Krebs \& N. B. Davies (Eds). Behavioral Ecology. London, Blackwell Scientific Publications.

Lima, M.S.P \& J.P. VieIRA. 2009. Variação espaço-temporal da ictiofauna da zona de arrebentação da Praia do Cassino, Rio Grande de Sul, Brasil. Zoologia 26 (3): 499-510.

Lima-Junior, S.E.; I.B. Cardone \& R. Goitein. 2002. Determination of a method for calculation of Allometric Condition Factor of fish. Maringá, Acta Scientiarum 24: 397-400.

Martins, S.E. \& A. Bianchini. 2008. Copper accumulation and toxicity in the Plata pompano Trachinotus marginatus Cuvier 1832 (Teleostei, Carangidae). Pan-American Journal of Aquatic Sciences 3 (3): 384-390 
Menezes, N.A. \& J.L. Figueiredo. 1980. Manual de peixes marinhos do sudeste do Brasil IV. Teleostei (3). São Paulo, Museu de Zoologia, Universidade de São Paulo, 96p.

Monteiro-Neto, C. \& L.P.R. Cunha. 1990. Seasonal and ontogenetic variation in food habits of juvenile Trachinotus marginatus Cuvier 1832 (Teleostei Carangidae) in the surf zone of Cassino Beach, RS, Brazil. Rio Grande, Revista Atlântica 12 (1): 45-54.

Monteiro-Neto, C.; L.P.R. Cunha \& J.A. Musick. 2003. Community Structure of Surf-zone Fishes at Cassino Beach, Rio Grande do Sul, Brazil. Journal of Coastal Research 35: 492-501.

Morato, T.; P. Afonso; P. Loirinho; J.P. Barreiros; R.S. Santos \& R.D.M. NASH. 2001. Length-weight relationships for 21 costal fish species of the Azores, North-eastern Atlantic. Fisheries Research 50: 297-302

Myers, R.H. 1990. Classical and modern regression with applications. Belmont, Duxbury, 488p.

Nirolsky, G.V. 1963. The ecology of fishes. London, Academic Press, 352p.

Oniye, S.J.; D.A. Adebote; S.K. Usman \& J.K. Makpo. 2006. Some aspects of the biology of Protopterus annectens (Owen) in Jachi dam near Katsina, Katsina state, Nigeria. Journal Fish Aquatic Science 1 (2): 136-141.

Potтs, G.W. \& R.J. Wootton. 1984. Fish Reproduction: Strategies and Tactics. London, Academic Press, 410p.

Ramos, L.R. \& J.P. Vieira. 2001. Composição específica e abundância de peixes de zonas rasas dos cinco estuários do Rio Grande do Sul, Brasil. São Paulo, Boletim do Instituto de Pesca 27 (1): 109-121.

Retta, S.; G. Martinez \& A. Errea. 2006. Áreas de cria de peces em la costa Uruguaya. In: R. Menafra; L. Rodríguez-Gallego; F. SCARABINo \& D. Conde (Eds). Bases para la conservación y el manejo de la Costa Uruguaya. Montevideo, Sociedad Uruguaya para la Conservación de la Naturaleza, 667p.
Ricker, W.E. 1973. Linear regressions in fishery research. Fisheries Research Board of Canada 30: 409-434.

Rossi-Wongtschowski, C.L.B. 1977. Estudo das variações da relação peso total-comprimento total em função do ciclo reprodutivo e comportamento de Sardinela brasiliensis (Steindachner, 1879) da costa do Brasil entre $23^{\circ} \mathrm{S}$ e $28^{\circ} \mathrm{S}$. Boletim Instituto Oceanográfico 26: 131-180.

Royce, W.F. 1972. Introduction to the fishery science. New York, Academic Press, 351p.

SAmpaio, L.A.; M.B. Tesser \& D. BurKerT. 2003. Tolerância de juvenis do pampo Trachinotus marginatus (Teleostei, Carangidae) ao choque agudo de salinidade em laboratório. Santa Maria, Ciência Rural 4 (33): 757-761.

SHINE, R. 1990. Proximate determinants of sexual differences in body size. American Naturalist 135: 278-283.

Smith-Vaniz, W.F; J.C. Quero \& M. Desoutter. 1990. Carangidae. In: J.C. Quero; J.C. Hureau, C. Karrer, A. Post \& L. Saldanha. Checklist of the fishes of the eastern tropical Atlantic (CLOFETA). JNICT, Lisbon; SEI, Paris and UNESCO, Paris, vol. 2.

Sylla, S; C.A. Boua \& J.K. N’Guessan. 2009. Stratégie Reproduction du Carangidae Trachinotus teraia (Cuvier 1832) dans la lagune Ebrié (Côte d'Ivoire). Sciences and Nature 6 (1): 83-94.

Tesser, M.B.D.; D. Burkert \& L.A. SAmpaio. 1998. Crescimento e sobrevivência de juvenis de pampo Trachinotus marginatus (Carangidae) em diferentes salinidades, p: 601-603. In: Anais Semana Nacional de Oceanografia. Rio Grande.

Vasconcellos, R.M.; J.N.S. Santos; M.A. Silva \& F.G. Araújo. 2007. Efeito do grau de exposição às ondas sobre a comunidade de peixes juvenis em praias arenosas no Município do Rio de Janeiro, Brasil. Campinas, Biota Neotropica 7 (1): 93-100.

VAZzoler, A.E.A. DE M. 1996. Biologia da reprodução de peixes teleósteos: teoria e prática. Maringá, Universidade Estadual de Maringá, 169p.

ZAR, J.H. 1999. Biostatistical analysis. New Jersey, PrenticeHall, $4^{\text {th }}$ ed., 663p.

Submitted: 10.I.2011; Accepted: 14.VII.2011.

Editorial responsibility: Cassiano Monteiro Neto 